\title{
Energy Consumption of Small Rodent Populations in Two Irish Woodland Ecosystems
}

\author{
C. M. SMAL \& J. S. FAIRLEY
}

Smal C. M. \& Fairley J. S., 1981: Energy consumption of small rodent populations in two Irish woodland ecosystems. Acta theriol., 26, 30: 449-458 [With 4 Tables].

The energy flow through populations of wood mice Apodemus sylvaticus and bank voles Clethrionomys glareolus was studied in an oak Quercus petraea wood and in a yew Taxus baccata wood at Killarney, south-west Ireland, from 1975 to 1977 . The energy requirements of the populations were calculated from capture-recapture data using information on metabolic rate, assimilation coefficients and calorific value of body obtained from the literature - data for Apodemus flavicollis was of necessity, substituted for A. sylvaticus. The proportion energy devoted to production was 2.8 to $3.3 \%$ of assimilated energy for mice and 2.3 to $2.5 \%$ for voles. The proportion of available, palatable fruit material consumed varied considerably, from 6.5 to $50.8 \%$, depending on the size of crops and on the size of the small mammal populations. Overall, however, it was low: $13 \%$ in the yew wood and $12 \%$ in the oak wood, averaged over the period of study. The proportion of primary production consumed did not show as much variation, the values ranging from 0.16 to $0.37 \%$. It was concluded that small mammals in woodlands are generally inefficient consumers of fruits because of the dramatic seasonal and annual variations in fruit fall.

[Dept. Zool., University College, Galway, Ireland].

\section{INTRODUCTION}

Information on the availability of natural foods and their consumption by small mammals is surprisingly scanty in studies carried out in the British Isles, although such data are necessary if we wish to understand the role of small mammals and the mechanisms involved in regulation of their numbers. Of the few such studies that there are, those of Tanton (1965) and Varley (1970) were very approximate, and that of Flowerdew \& Gardner (1978) was, for special reasons, inconclusive. Considerably more work has been done on the role of small mammals in energy flow elsewhere: there are now data from woodland ecosystems (e.g. Drożdż, 1966; Ryszkowski, 1969; Hansson, 1971a, 1971b, 1974; Migula et al., 1975), old-field communities (Golley, 1960; Odum et al., 1962), meadows (Pearson, 1964), a desert shrub community (Chew \& Chew, 1970), a low peat bog (Gębczyńska, 1970) and taiga forest (Grodziński, 1971). 
The purpose of this paper is to examine the efficiency of small rodent populations in utilising their energy resources in two woodlands: to determine the proportions consumed of the net above-ground primary production and of the fruits potentially available to small mammals. It forms part of a larger investigation of the role of small mammals and the regulation of their numbers in woodlands of the Killarney National Park in south-west Ireland. The work was carried out on two populations, one in sessile oak Quercus petraea wood and the other in a yew Taxus baccata wood. The only rodents captured were the wood mouse Apodemus sylvaticus (Linnaeus, 1758) and the bank vole Clethrionomys glareolus (Schreber, 1780), the former being much more numerous than the latter in both areas. The population dynamics of both species were determined by capture-recapture techniques (Smal \& Fairley, 1981b) and their diets examined in the laboratory and in the field (Smal \& Fairley, 1980b); the production of fruits was monitored by means of seed traps and the quantities of palatable fruit potentially available to small mammals thus defined (Smal \& Fairley, 1980a); the primary production of the woodlands was also estimated (Smal \& Fairley, 1981a). The production of fungi was not included in the latter study.

\section{STUDY AREAS, MATERIALS AND METHODS}

The study areas, in Tomies oak wood and Reenadinna yew wood are fully described in Smal \& Fairley (1980a). Within the oak wood a study plot of 5.76 ha $(240 \times 240 \mathrm{~m})$ was established, but a smaller plot of 3.24 ha $(180 \times 180 \mathrm{~m})$ was chosen in the yew wood.

The oak wood, standing on a lateral moraine consisting mainly of Old Red Sandstone, is composed virtually exclusively of mature, native oak with a well developed understorey of holly Ilex aquifolium. The ground vegetation is dominated by mosses, the herb layer being sparse because of shade and heavy grazing by deer. The yew wood, mainly on limestone pavement, also has a sparse herb layer due principally to the heavy shade cast by the yew canopy: a thick layer of mosses covers most of the ground surface. Hazel Corylus avellana, ash Fraxinus excelsior and holly are frequent. Abuot $12 \%$ of the study plot is dominated by oak with a richer ground flora. Since the ground vegetation is very poor in both areas, the fruit production of this component is negligible and was ignored.

Primary production and fruit production were estimated over a period of approximately 19 months, from August/September 1975 to March 1977, which included two complete fruit crops in each wood. Live trapping of small mammals was sarried out at approximately 5.5 week intervals until 1976 and concurrently on smaller "index" grids of 0.36 ha $(60 \times 60 \mathrm{~m})$, superimposed upon the larger study plots, ot 10.5 week intervals. Trapping on the index grids provided the data on population densities on the larger grids after trapping on the latter had 
terminated. Population density at each trapping session was determined by dividing the estimate of population size by the effective trapping area, the latter being the area of the grid plus a bound boundary strip measuring half the mean range length across.

A considerable quantity of bait (barley) was used in the course of live-trapping, for which allowance was made, by subtracting the quantity of grain supplied from the estimates of consumption, to give values for natural food consumed. $16.9 \mathrm{~g}$ of barley was removed per capture, this value being obtained from data on five trapping sessions in both study areas. All the barley utilised was assumed to have been eaten eventually by small mammals.

\section{RESULTS}

In order to relate consumption by small mammals to the food supply and primary production studies, three periods were considered:

(i) the entire period of the primary production study,

(ii) 1976 alone - the only full year for which complete data on primary production were available,

(iii) the period extending from the first fruit fall to the beginning of the next (August/September 1975 to June 1976).

Consumption was calculated by determining maintenance and production costs (assimilation) and making an allowance for energy expelled in the form of faeces and urine. For C. glareolus the maintenance costs were calculated using the data for daily energy budget $(D E B)$ given by Grodziński \& Górecki (1967). No such corresponding information is available for A. sylvaticus so data for Apodemus flavicollis (Melchior, 1830) were used instead (Gębczyński, 1966). Multiplication of the DEB by the number of biomass days gives the maintenance costs of the populations which are given in Table 1 .

An approximate estimate was obtained for the production of the small mammal populations by using the formula suggested by Ryszkowski \& Petrusewicz (1967):

$$
P=N_{t} \cdot W_{m}
$$

where $N_{t}$ is the total number of individuals present at any time over the period, $T$, and $W_{m}$ is the average weight attained by these individuals. $N_{t}$ was obtained for these intervals by the relationship

$$
N_{t}=\bar{n} \cdot \Theta \cdot T
$$

where $\bar{n}$ is the mean number of individuals present over time $T$ and $\Theta$ is the turnover of individuals per unit time. A calorific value of $1.5 \mathrm{kcal} \mathrm{g}^{-1}$ (fresh weight) of the body of small rodents (Górecki, 1965) was used to give the production in energy terms. 
Consumption was given by adding a correction for the quantity of energy used in faeces and urine (Drożdż, 1968). As before, data for $A$. flavicollis were used for $A$. sylvaticus. Results are presented in Table 1.

In 1976 the energy consumed by the small mammals in the yew wood was just under twice that in the oak wood. However, over other periods the difference between the two areas is more apparent, with the figure for the yew wood over three times that in the oak wood over the period of fruit fall in the first crop.

Table 1

Estimates of production, maintenance and total consumption of the small mammal populations.

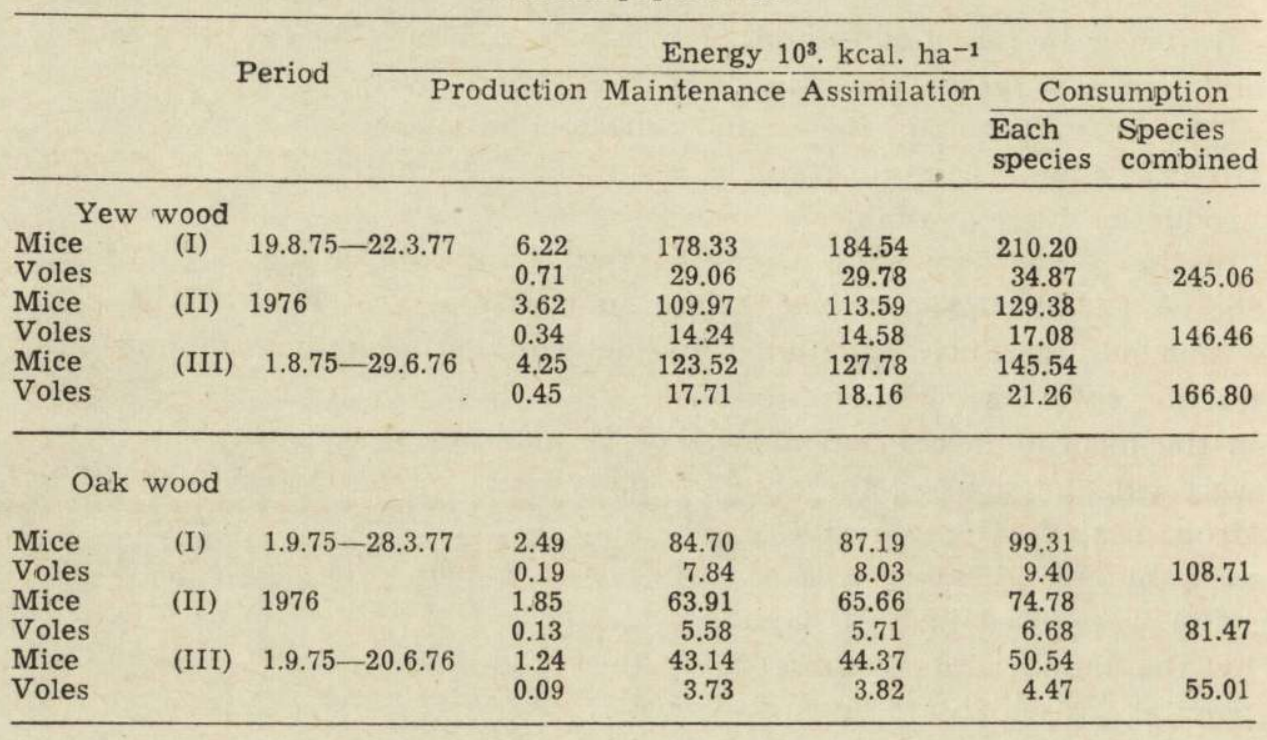

Table 2 gives results for net above-ground primary production, energy invested in fruit production, total potentially available to the rodents, and the requirements of the populations. The total barley supplied during live-trapping is also included. The diet of both mice and voles included material other than fruits. Corrections to the observed seasonal variation in diet, studied in Smal \& Fairley (1980b), were applied to allow for changes in the density of mice. The proportions of fruit material and of green and woody plant material are given in Table 3. For bank voles, the data is less reliable due to small sample sizes and a single value was obtained for the entire period of study.

The percentages of potentially available fruit supply and of primary production consumed are given in Table 4 . The values clearly show much variation - from $6.5 \%$ to $50.8 \%$ of the available fruit supply 
was taken. The large amount of variation is a result of the large differences in the size of seed crops in the two years of the study and in the size of the small mammal populations. Thus, in 1976, mice and voles in the oak wood appeared to have utilised a large proportion of

Table 2

Net above-ground primary production, food supply and consumption by small mammal populations.

\begin{tabular}{|c|c|c|c|c|c|c|c|}
\hline \multirow{3}{*}{ Period } & \multicolumn{3}{|c|}{ Energy $10^{3} . \mathrm{kcal} . \mathrm{ha}^{-1}$} & & & & \\
\hline & \multirow{2}{*}{$\begin{array}{l}\text { Primary } \\
\text { prodution }\end{array}$} & \multirow{2}{*}{$\begin{array}{c}\text { Fruit } \\
\text { prodution }\end{array}$} & \multirow{2}{*}{$\begin{array}{c}\text { Total } \\
\text { palatable } \\
\text { fruit } \\
\text { material }\end{array}$} & \multicolumn{2}{|c|}{$\begin{array}{c}\text { Consump- } \\
\text { tion }\end{array}$} & \multicolumn{2}{|c|}{$\begin{array}{c}\text { Grain } \\
\text { supplied }\end{array}$} \\
\hline & & & & Mice & Voles & Mice & Voles \\
\hline \multicolumn{8}{|l|}{ Yew wood } \\
\hline $19.8 .75-22.3 .77$ & $50,122.3$ & $3,549.3$ & $1,264.5$ & 210.2 & 34.9 & 33.6 & 7.5 \\
\hline 1976 & $30,348.9$ & $2,871.8$ & $1,056.9$ & 129.4 & 17.1 & 18.2 & 3.1 \\
\hline $1.8 .75-29.6 .76$ & - & 828.7 & 208.1 & 145.5 & 21.3 & 29.8 & 6.6 \\
\hline \multicolumn{8}{|l|}{ Oak wood } \\
\hline 1.9.75-28.3.77 & $50,567.2$ & $1,618.7$ & 657.3 & 99.3 & 9.4 & 16.6 & 1.7 \\
\hline 1976 & $28,559.0$ & 672.4 & 115.8 & 74.8 & 6.7 & 13.4 & 1.3 \\
\hline $1.9 .75-20.6 .76$ & - & $1,028.9$ & 541.6 & 50.5 & 4.5 & 14.1 & 1.2 \\
\hline
\end{tabular}

Table 3

Consumption of fruits and other plant material by small mammal populations allowing for both the proportion of these items in the diet and the quantity of grain supplied during live-trapping. Results for voles are unreliable due to small sample sizes.

\begin{tabular}{|c|c|c|c|c|c|c|c|c|c|}
\hline \multirow{3}{*}{5} & \multirow{3}{*}{ Period } & \multicolumn{4}{|c|}{ Fruit material } & \multicolumn{4}{|c|}{$\begin{array}{l}\text { Green and woody } \\
\text { plant material }\end{array}$} \\
\hline & & \multicolumn{2}{|c|}{ Percentage in diet } & \multicolumn{2}{|c|}{$\begin{array}{c}\text { Consumption } \\
10^{3} \text {. kcal. ha } \text { ha }^{-1} \\
\end{array}$} & \multicolumn{4}{|c|}{$\begin{array}{l}\text { Percentage Consumption } \\
\text { in diet } 10^{3} . \mathrm{kcal}^{-\mathrm{ha}^{-1}} \\
\end{array}$} \\
\hline & & Mice & Voles & Mice & Voles & Mice & Voles & Mice & Voles \\
\hline $\begin{array}{l}\text { (I) } \\
\text { (II) } \\
\text { (III) }\end{array}$ & $\begin{array}{l}\text { Yew wood } \\
19.8 .75-22.3 .77 \\
1976 \\
1.8 .75-29.6 .76\end{array}$ & $\begin{array}{l}87.5 \\
77.0 \\
81.0\end{array}$ & $\begin{array}{c}33.0 \\
, " \\
,\end{array}$ & $\begin{array}{r}154.5 \\
85.6 \\
93.7\end{array}$ & $\begin{array}{l}9.0 \\
4.6 \\
4.9\end{array}$ & $\begin{array}{l}3.0 \\
3.3 \\
3.0\end{array}$ & $\begin{array}{c}67.1 \\
” \\
"\end{array}$ & $\begin{array}{l}5.3 \\
3.7 \\
3.5\end{array}$ & $\begin{array}{r}18.4 \\
9.4 \\
9.9\end{array}$ \\
\hline $\begin{array}{l}\text { (I) } \\
\text { (II) } \\
\text { (III) }\end{array}$ & $\begin{array}{l}\text { Oak wood } \\
1.9 .75-28.3 .77 \\
1976 \\
1.9 .75-20.6 .76\end{array}$ & $\begin{array}{l}95.9 \\
95.8 \\
96.2\end{array}$ & $\begin{array}{c}0.3 \\
" \\
"\end{array}$ & $\begin{array}{l}79.3 \\
58.8 \\
35.0\end{array}$ & $\begin{array}{l}0.0 \\
0.0 \\
0.0\end{array}$ & $\begin{array}{l}0.3 \\
0.5 \\
0.3\end{array}$ & $\begin{array}{c}73.6 \\
" \\
"\end{array}$ & $\begin{array}{l}0.2 \\
0.3 \\
0.1\end{array}$ & $\begin{array}{l}5.7 \\
4.0 \\
2.4\end{array}$ \\
\hline
\end{tabular}

the food available. The density of small mammals throughout that year was high because of the previous year's good acorn crop, but the food supply from the 1976 crop was low.

The percentages of primary production consumed do not show as much variation, ranging from 0.16 to $0.37 \%$. 


\section{DISCUSSION}

\subsection{Production, Assimilation and Consumption}

The relation of net production to assimilation was under $4 \%$ for both species in both areas. The highest proportion of energy devoted to production was by mice in the yew wood - 3.3\% of assimilated energy - and the value was sligthly lower for mice in the oak wood - $2.8 \%$. In both areas this percentage was smaller for voles: in the yew wood 2,4 to $2.5 \%$ and in the oak wood 2.3 to $2.4 \%$. Considering that no account was taken of production of nestlings and juveniles

Table 4

Proportion of net above-ground primary production and of available fruit material consumed by small mammals. Only the palatable portion of fruits is considered.

\begin{tabular}{|c|c|c|c|}
\hline \multirow{2}{*}{\multicolumn{2}{|c|}{ Period }} & \multicolumn{2}{|c|}{$\begin{array}{l}\text { Percentage consumed, allowing for } \\
\text { proportions of fruits and other } \\
\text { plant material in the diet }\end{array}$} \\
\hline & & $\begin{array}{l}\text { Of palatable } \\
\text { fruit material }\end{array}$ & $\begin{array}{l}\text { Of primary } \\
\text { production }\end{array}$ \\
\hline & Yew wood & '́ & \\
\hline & $19.8 .75-22.3 .77$ & 12.9 & 0.37 \\
\hline & 1976 & 8.5 & 0.34 \\
\hline (III) & $1.8 .75-29.6 .76$ & 47.4 & - \\
\hline \multicolumn{4}{|c|}{ Oak wood } \\
\hline & $1.9 .76-28.3 .77$ & 12.1 & 0.16 \\
\hline & 1976 & 50.8 & .0 .22 \\
\hline (III) & $1.9 .75-20.6 .76$ & 6.5 & - \\
\hline
\end{tabular}

that do not survive to trappable age, or of seasonal weight changes in individuals, these proportions are high. The greatest value of seven small mammal species listed by Ryszkowski \& Petrusewicz (1967) was $2.8 \%$, but this does not include those in the present study. Using the same methods of calculation, Grodzinski et al. (1968) gave the efficiency of net production as $2.3 \%$ of the energy assimilated for C. glareolus and $A$. flavicollis combined.

\subsection{Role in Energy Flow}

In this study only a very small proportion - up to $0.37 \%$ in the yew wood 2.4 to $2.5 \%$ and in the oak wood 2.3 to $2.4 \%$. Considering duction was consumed by small mammals. They clearly played an insignificant role in the flow of energy through both ecosystems, and this has been the conclusion of research in other woodlands. In beech Fagus sylvatica forest, Grodziński et al. (1968) found that small rodents 
utilised only $0.19 \%$ of the total, and Migula et al. (1975) found the proportion to be $0.28 \%$. Ryszkowski $(1969 / 70)$ gave higher values for five woodlands, ranging from 0.6 to $1.9 \%$ but these are certainly excessive as the estimates of primary production included only the herb layer and the fall of leaves and seeds, and ignored woody material. Hansson (1974) found that up to $2 \%$ of primary production was taken, but he only considered the production of the field layer.

In the only comparable studies therefore - the two beech forests in Poland - the percentage consumed was lower than that found in Reenadinna yew wood. However, other habitat types generally exhibit a higher consumption of primary production by small mammals. For example Dipodomys merriami (Mearns, 1890) accounted for $1.5 \%$ of net production in Larrea desert shrub (Chew \& Chew, 1970), Microtus pennsylvanicus (Ord, 1815) $1.6 \%$ of production of an old-field community (Golley, 1960), and Peromyscus polionotus (Wagner, 1843) 0.8\% (Odum et al., 1962).

Since small mammals concentrate their feeding in particular components of primary production, they are capable of exerting a considerable influence on the functioning of the ecosystem, although their overall role in energy flow may be negligible. Thus, in poor seed years, up to $51 \%$ of the total production of palatable fruit was eaten in the study areas. Together with other consumers of seeds on the ground, it is possible that almost $100 \%$ of seeds could be eaten in some years. In particular the seeds of some species would be more affected than others - such as the attractive acorns or yew fruits. Presumably large seeds are more likely to be found than small ones. On the other hand, in good seed years small rodents removed as little as $6.5 \%$ in this study.

Extensive removal of seeds has been noted in other work. Chew \& Chew (1970) found that as much as $87 \%$ of seeds produced by a desert shrub community were consumed by mammals and, in France, Le Louarn \& Schmitt (1972) noted that $74 \%$ of beechnuts may have been removed by small rodents in one year of their study. In Western Oregon rodents destroyed an estimated $41 \%$ of the seed of Douglas fir Pseudotsuga menziesii (Gashwiler, 1970).

Generally, however, the proportion of the food potentially available that is eaten is relatively low - under $15 \%$ (review by Chew \& Chew, 1970; also Tanton, 1965; Grodziński, 1971; Hansson, 1974; Migula et al., 1975). In this study, averaged over the two years, the proportion taken was only $13 \%$ in the yew wood and $12 \%$ in the oak wood: this similarity may be coincidence, but it might indicate a long-term upper limit to consumption by small rodents in woodland ecosystems in the 
British Isles or, indeed, elsewhere.

Chew \& Chew (1970) considered that the efficiency with which a species utilises the energy resources that are potentially available is an an index of its adaptation to the system. In this context small mammals here and elsewhere are generally inefficient, consuming on average less than $15 \%$ of their potential food. This generally low consumption results from an inability to adapt more economically to both seasonal and annual variations in food supply, which may be dramatic.

Acknowledgement: this work was financed by the Office of Public Works, Dublin. We would also like to thank Eden Thomson for practical help and Professor A. Macfadyen for useful discussion.

\section{REFERENCES}

1. Chew R. M. \& Chew A. E., 1970: Energy relationships of the mammals of a desert shrub (Larrea tridentata) community. Ecol. Monogr., 40: 1-21.

2. Drożdż A., 1966: Food habits and food supply of rodents in the beech forests. Acta theriol., 11: 363-384.

3. Drożdż A., 1968: Digestibility and utilisation of natural foods in small rodents. Acta theriol., 13: 367-389.

4. Flowerdew J. R. \& Gardner G., 1978: Small rodent populations and food supply in a Derbyshire ashwood. J. Anim. Ecol., 47: 725-740.

5. Gashwiler J. S., 1970: Further study of conifer seed survival in a Western Oregon clearcut. Ecology, 51: 849-854.

6. Gębczyńska Z., 1970: Bioenergetics of root vole population. Acta theriol., 15: $33-66$.

7. Gębczyński M., 1966: The daily energy requirement of the yellow-necked field mouse in different seasons. Acta theriol., 11: 391-398.

8. Golley F. B., 1960: Energy dynamics of a food chain of an old-field community. Ecol. Monogr., 30: 187-205.

9. Górecki A., 1965: Energy values of body in small mammals. Acta theriol., 10: $333-352$.

10. Grodziński W., 1971: Food consumption of small mammals in the Alaskan taiga forest. Ann. Zool. Fennici, 8: 133-136.

11. Grodziński W., Bobek B., Drożdż A. \& Górecki A., 1968: Energy flow through small rodents in a beech forest. Small Mammal Newslett., 2: 146-150.

12. Grodziński W. \& Górecki, A. 1967: Daily energy budgets of small mammals. [In: "Secondary productivity of terrestrial ecosystems", K. Petrusewicz, ed.]: 295-314. Polish Sci. Publ. Warszawa.

13. Hansson L., 1971a: Estimates of the productivity of small mammals in a South Swedish spruce plantation. Ann Zool. Fennici, 8: 118-126.

14. Hansson L., 1971b: Small rodent food, feeding and population dynamics (a comparison between granivorous and herbivorous species in Scandinavia). Oikos, 22: 183-198.

15. Hansson L., 1971: Small mammal productivity nad consumption in spruce forest and reafforestation in south Sweden, Oikos, 25: 153-156. 
16. Le Louarn H. \& Schmitt A., 1972: Interrelationships between beechnutproduction and population-dynamics of fieldmouse, Apodemus sylvaticus in the forest of Fontainebleau. Ann. Sci. forest., 30: 205-214.

17. Migula P., Gano B., Stępień Z. \& Bugdal U.. 1975: Density estimation and energy flow through small mammal populations in the beech forest of $\mathrm{Za}$ skalskie Gorge (Pieniny Małe). Przegl. zool., 19: 467-474. [In Polish with English summ.].

18. Odum E. P., Connell C. E. \& Davenport L. B., 1962: Population energy flow of three primary consumer components of old-field ecosystems. Ecology, 43: 88-96.

19. Pearson O. P., 1964: Carnivore-mouse predation: an example of its intensity and bioenergetics. J. Mammal., 45: 177-188.

20. Ryszkowski L., 1969/1970: Estimates of consumption of rodent populations in different pine forest ecosystems. [In: "Energy flow through small mammal populations", K. Petrusewicz, L. Ryszkowski, eds.]: 281-289. Polish Sci. Publ. Warszawa.

21. Ryszkowski L. \& Petrusewicz K., 1967: Estimation of energy flow through small mammal populations. [In: "Secondary productivity of terrestrial ecosystems", K. Petrusewicz, ed.]: 125-146. Polish Sci. Publ. Warszawa.

22. Smal C. M. \& Fairley J. S., 1980a: The fruits available as food to small rodents in two woodland ecosystems. Holarctic Ecology, 3: 10-18.

23. Smal C. M. \& Fairley J. S., 1980b: Food of wood mice and bank voles in oak and yew woods at Killarney, Ireland. J. Zool., Lond., 191: 413-418.

24. Smal C. M. \& Fairley J. S., 1981a: Primary production in two Irish woods and the fraction available to small mammals as food. Ir. Nat. J., 20: 173-179.

25. Smal C. M. \& Fairley J. S., 1981b: The dynamies and regulation of small rodent populations in the woodland ecosystems of Killarney, Ireland. J. Zool., Lond., In press.

26. Tanton M. T., 1965: Acorn destruction potential of small mammals and birds in British woodlands. Q. J1 For., 59: 230-234.

27. Varley G. C., 1970: The concept of energy flow applied to a woodland community. [In: "Animal populations in relation to their food resources", A. Watson, ed.]. Blackwell Press: 389-405. Oxford.

Accepted, May 13, 1981.

\section{M. SMAL i J. S. FAIRLEY}

\section{ZAPOTRZEBOWANIE ENERGETYCZNE POPULACJI MAEYCH GRYZONI W DWOCH IRLANDZKICH EKOSYSTEMACH LESNYCH}

\section{Streszczenie}

W latach 1975-1977 badano przepływ energii przez populację Apodemus sylvaticus $i$ Clethrionomys glareolus $\mathrm{w}$ dąbrowie (Quercus petraea) i lesie cisowym (Taxus baccata) w południowo-zachodniej Irlandii. Zapotrzebowanie energetyczne populacji obliczano na podstawie danych uzyskanych ze złowień w pułapki żywolowne i wypuszczeń gryzoni i norników oraz informacji o poziomie metaboliz$\mathrm{mu}$, współczynniku asymilacji i wartości kalorycznej ciała, uzyskanych z litera- 
tury (Tabela 1). $\mathrm{Z}$ braku wiadomości dotyczących bezpośrednio A. sylvaticus, zastąpiono je danymi dla $A$. flavicollis. Produkcję pierwotną i produkcję owoców oceniano w ciągu 19 miesięcy, od przełomu sierpnia i września $1975 \mathrm{r}$. do marca 1977 r. Oceną objęto 2 sezony owocowania w każdym typie lasu.

Udział energii wydatkowanej na produkcję stanowił dla myszy $2.8-3.3 \%$ zasymilowanej energii, a dla norników 2.3-2.5\%. Procent dostępnych owoców w pokarmie zmieniał się znacznie od $6.5 \%$ do $50.8 \%$, zależnie od urodzaju na nie, jak i od wielkości populacji małych ssaków. Ogólnie jednak był niski i wynosił, w okresie prowadzenia badań, $13 \%$ w lesie cisowym i $12 \%$ w dąbrowie (Tabele 2, 3). Udzial zjadanej produkcji pierwotnej nie wykazywal tak dużych zmian i wahał się w granicach od 0.16 do $0.37 \%$ (Tabela 4 ).

$\mathrm{Na}$ podstawie prowadzonych badań wyciągnięto wniosek, że małe ssaki w omawianych lasach, są mało znaczącymi konsumentami owoców, z powodu ogromnych różnic między poszczególnymi sezonami i latami w urodzaju tych owoców. 